\title{
Pembentukan Opini Publik oleh Media: Cable News Network (CNN) Indonesia dalam 2018 North Korea-United States Singapore Summit
}

\author{
Alya Dalila \\ Chandra Purnama \\ Universitas Padjadjaran
}

\begin{abstract}
It is undeniable that media is mostly used as a propaganda tool of the political elite to achieve the national interest of its country. This research identifies and explains the establishment of CNN Indonesia in making public opinion as one of the extensions on CNN International regarding the Kim Jong Un and Donald Trump Summit in Singapore in 2018. This research utilized: agenda-setting, priming and framing theory to find out the detail process of forming public opinion by CNN Indonesia. This research also utilizes qualitative research methods based on Robert E. Stake's explanation. The finding suggests that CNN Indonesia, through its agenda-setting, was able to make the summit has an urgency to be discussed in public. Its priming is able to increasing awareness of the importance of denuclearization and world peace which has been Indonesa's foreign policy agenda. Through its framing, CNN Indonesia attempted to construct public opinion that the United States able to utilize its super power label in order to perquisite many parties, namely creating the world peace.
\end{abstract}

Keywords: global media, Donald Trump, United States, Kim Jong Un, North Korea, public opinion

\begin{abstract}
Abstrak
Tidak dapat dipungkiri bahwa media seringkali masih dijadikan sebagai alat propaganda yang banyak ditumpangi kepentingan-kepentingan elit politik guna mencapai tujuan negaranya. Penelitian ini mengidentifikasi dan memaparkan upaya pembentukan opini publik yang dilakukan oleh CNN Indonesia sebagai salah satu media kepanjangan dari CNN Internasional berkenaan dengan Pertemuan Kim Jong Un dan Donald Trump di Singapura tahun 2018 lalu. Penelitian ini menggunakan teori agenda-setting, priming, dan framing untuk mengetahui secara detail proses pembentukan opini publik oleh CNN Indonesia. Penelitian ini juga menggunakan metode penelitian kualitatif dengan merujuk pada penjelasan dari Robert E. Stake. Hasil penelitian menunjukkan bahwa CNN Indonesia, melalui agenda-setting yang dilakukanya mampu membuat fenomena ini memiliki urgensi untuk dibicarakan di ruang publik. Sedangkan primingnya mampu membangun kesadaran akan pentingnya denuklirisasi dan berkontribusi menciptakan perdamaian dunia yang selama ini telah menjadi agenda politik luar negeri Indonesia. Selain itu, melalui framing yang dilakukan CNN Indonesia ditemukan bahwa CNN Indonesia berupaya untuk mengkonstruksi opini publik bahwa Amerika Serikat merupakan demokratis yang dapat memanfaatkan label super power nya untuk kepentingan banyak pihak, yaitu menciptakan perdamaian dunia.
\end{abstract}

Kata-kata kunci: media global, Donald Trump, Amerika Serikat, Kim Jong Un, Korea Utara, opini publik 


\section{Pendahuluan}

Dalam perkembangannya, Hubungan Internasional sebagai sebuah disiplin ilmu telah memasuki titik dimana sistem internasional tidak lagi menjadi bahasan utama dan Hubungan Internasional juga bersifat nonstatism (Baylis, Smith, \& Owens, 2014). Negara tidak lagi menjadi satusatunya aktor yang berperan dalam mencapai tujuan dari kepentingan nasional, terutama dalam negara demokrasi liberal. Prinsip-prinsip dalam demokrasi menuntut pemerintah untuk mempertimbangkan opini publik yang ada dalam masyarakat dalam mencapai kepentingan nasionalnya (Robinson, 2008). Salah satu aktor non-negara yang hadir dalam Hubungan Internasional adalah media global. Media global memiliki kapabilitas dalam menempatkan sebuah fenomena dalam agenda prioritas sehingga dapat dikatakan bahwa pembentukan opini publik dalam prosesnya sangat bergantung pada bagaimana narasi yang dibawakan oleh media (Hill, 2003). Inti dari pembentukan opini publik yang dilakukan oleh media dapat dibagi menjadi tiga, yaitu agenda-setting, priming, dan framing.

Salah satu media global raksasa yang banyak diminati oleh publik adalah Cable News Network (CNN) yang didirikan pada tahun 1980 dari Amerika Serikat dengan Ted Turner sebagai pelopornya. CNN telah menjadi kiblat bagi negara-negara lain dalam menyajikan pemberitaan mengenai fenomena internasional. Sebagai sebuah media global, CNN mengembangkan jangkauannya dengan membuka cabang dinegara-negara diseluruh dunia, tidak terkecuali Indonesia. Situs berita CNN Indonesia telah dinikmati masyarakat sejak 2014. Kerjasama atara CNN Internasional dan CNN Indonesia diyakini akan membantu masyarakat Indonesia untuk dapat memahami dunia dengan lebih baik dan yang penting adalah membantu dunia untuk memahami Indonesia (Deil, 2014). Pada tanggal 12 September 2018 di Singapura telah terjadi fenomena bersejarah yang menarik perhatian bayak kalangan, terutama media. Hari itu telah terjadi pertemuan antara Donald Trump dan Kim Jong Un untuk pertama kainya setelah bersitegang bertahun lamanya. Rencana pertemuan ini tercetus saat pertemuan Korea Utara dan Korea Selatan berjalan dengan baik dan hal ini membuat Amerika Serikat ingin menciptakan peluang untuk berdiskusi bersama Korea Utara terkait denuklirisasi.

Meskipun terjadi banyak dinamika tarik ulur selama proses perencanaanya, pertemuan tersebut tetap berlangsung sesuai rencana awal dan berjalan dengan lancar. Diakhir pertemuan, sebuah pernyataan yang telah disepakati dan ditandatangi keduanya dirilis dengan poinpoin kesepakatan bersama terkait denuklirirsasi, Hak Asasi Manusia, perbaharuan hubungan antara Amerika Serikat dengan Korea Utara dan memastikan perdamaian jangka panjang di Semenanjung Korea. Pertemuan antara Kim dan Trump di Singapura kala itu menjadi headline seluruh media global, termasukk CNN. Selain CNN Internasional, CNN Indonesia sebagai salah satu cabang CNN yang ada di Asia tentunya tidak ingin melewatkan kesempatan dalam memberitakan fenomena pertemuan 
antara Kim dan Trump di Singapura 2018 lalu. Meskipun CNN Indonesia dikatakan sebagai organisasi independen dan berusaha menyajikan pemberitaan terkait fenomena ini dengan netral, tetapi tidak dapat dipungkiri bahwa CNN Indonesia merupakan kepanjangan yang tentunya masih memiliki kesamaan prinsip dan keterkaitan secara psikologis dalam menyajikan berita dengan CNN Internasional. Eksistensi yang dimiliki oleh CNN Indonesia tidak terlepas dari citra CNN Internasional, sehingga akan ada keterkaitan serta keselarasan yang cukup erat antar dua media ini dalam menyajikan berita terkait fenomena pertemuan Kim dan Trump.

Menurut Dirk Simile, mengenai kunci dari obyektivitas media adalah memberikan perlakuan yang sama bagi setiap pihak terkait dalam pemberitaan (Smilie, 2013). Smilie mengambil contoh saat perang Amerika Serikat dan Irak berlangsung. Saat itu terdapat perbedaan konstruksi suatu fenomena oleh dua media global, yaitu CNN dan Al-Jazeera. CNN berusaha membuat publik berpikir bahwa Amerika telah membebaskan Irak dari presiden yang diktator dan kelompok elit politik yang radikal, sedangkan Al-Jazeera mengemas berita seakan-akan Amerika penyebab utama dari kondisi menyedihkan dan meresahkan di Irak saat itu. Kedua media global tersebut berusaha membentuk opini publik bergantung pada kepentingan yang menduduki atau diduduki mereka, sehingga hal itu membuktikan bahwa objektivitas dari media merupakan hal yang sulit untuk diperoleh.

Hal yang sama juga disampaikan oleh Filiz Coban terkait media. Coban mengatakan bahwa media merupakan suatu sarana yang mampu menerjemahkan suatu fenomena agar mudah dicerna oleh publik (Coban, 2016). Peran kekuasaan media dalam politik domestik yang kerap kali dijadikan sebagai watchdog atau penjaga. Penjaga disini memiliki arti bahwa media memiliki fungsi untuk memilih, mengatur, dan menekankan secara khusus untuk memutuskan fenomena apa yang penting untuk menjadi bahan diskusi publik. Media tidak bisa memaksa masyarakat untuk berpikir, tetapi media mampu memengaruhi apa dan bagaimana publik berpikir. Hal itu disebut sebagai agenda building yang dapat digunakan untuk membujuk atau memanipulasi publik sehingga media dapat dikatakan sebagai salah satu aktor non-negara. Hubungan antara media dan politik memiliki tingkat interdepedensi yang tinggi dimana keduanya saling ditunggangi kepentingan masing-masing.

Artikel ini berusaha untuk menjelaskan bagaimana CNN Indonesia, sebagai salah satu kepanjangan media global yang hadir ditengah negara penjunjung demokrasi serta sebagai negara sahabat yang telah menjalin hubungan diplomatik yang erat dengan Amerika Serikat dan Korea Utara selama bertahun-tahun, meliput pertemuan antara pimpinan kedua negara tersebut sehingga kemudian mampu menjadi instrumen bagi terbentuknya opini publik. Rumusan masalah yang dijadikan acuan dalam artikel ini ialah "Bagaimana pembentukan opini publik yang dilakukan oleh CNN Indonesia berkenaan dengan pertemuan Kim Jong Un dan Donald Trump di Singapura tahun 2018?" 


\section{Pembentukan Opini Publik oleh Media Global}

Pola alur komunikasi masyarakat saat ini telah mengalami perubahan penting sebagaimana konsekuensi dari berkembangnya ruang publik digital dan pemebentukan sistem media hibrida (Chadwick, 2013). Salah satu manifestasi dari perkembagan tersebut adalah lahirnya media global. Media global mengindikasikan perluasan jangkauan penyebaran hingga skala dunia internasional. Salah satu karakteristik dari media global adalah sifatnya yang ekspansif, yaitu akan terus melakukan perluasan dalam bidang distribusinya dengan membuka cabang atau membeli saham media-media dari berbagai negara.

Muncul dan berkembangnya media global dinilai mampu untuk mengatasi batasan dan hambatan yang ada terkait dengan kecepatan waktu yang dibutuhkan dalam menyampaikan informasi kepada publik sehingga publik dapat menerima informasi dengan lebih akurat. Perkembangan yang ditawarkan oleh media global merupakan salah satu bentuk upaya terciptanya interkonetivitas antara masyarakat diberbagai belahan dunia.

Program World Report yang disiarkan oleh CNN menjadi tahap awal dari lahirnya media yang mampu menarik audiens dari berbagai belahan dunia (Flournoy, 1992). Program yang diperkasai oleh Ted Turner selaku pendiri dari $\mathrm{CNN}$, di dalamnya menayangkan pemberitaan mengenai berbagai fenomena yang terjadi di dunia yang dibawakan oleh reporter lokal negara tersebut. Melalui program ini, publik dengan mudah dapat memperoleh informasi serta perkembangan mengenai sebuah fenomena melalui sudut pandang lokal wilayah yang mengalami.

Media global seperti CNN sering kali dijadikan sarana dalam menyebarkan dan mempromosikan isu internasional. Adanya hubungan yang tak bisa dipisahkan antara media dan politik maka kepentingan politik media dapat dilihat dengan beberapa cara. Salah satunya adalah kenyataan media global telah menciptakan apa yang dikenal sebagai global village dimana masyarakat mengalami perubahan dalam memandang dirinya sendiri dan juga orang lain. Dengan begitu, dapat dikatakan bahwa media mampu membentuk pola pikir manusia tentang dunia sehingga media global yang ada memiliki pengaruh besar dalam membentuk opini publik.

Menurut W.P Davidson, opini publik merupakan sebuah tindakan maupun preparasi dalam menghadapi adanya fenomena tertentu yang beredar dalam masyarakat dengan asumsi bahwa masyarakat lainnya juga berorientasi pada fenomena tersebut. Terbentuknya opini publik diawali dengan adanya pemusatan fenomena yang dilakukan oleh media (Price, 2011). Pemusatan dan pengulangan yang dilakukan oleh media berkenaan dengan teori dasar dari pembentukan opini publik yang muncul akibat perkembangan dari beberapa teori dan fenomena komunikasi baru, yaitu agenda-setting, priming, dan framing.

Dalam menelaah agenda-setting, intensitas pemberitaan media terhadap sebuah fenomena menjadi sebuah elemen penting karena agendasetting mengacu pada gagasan adanya korelasi tinggi antara media massa dan penempatan isu serta fenomena tertentu yang memiliki tingkat 
relevansi tinggi dengan publik (McCombs \& Shaw, 1972). Agenda-setting dimulai dengan asusmsi bahwa media massa memiliki kendali penuh atas berita-berita yang ingin disajikan sesuai dengan intensi dari media tersebut. Penetapan agenda yang dilakukan oleh media akan turut menetapkan mekanisme publik dalam berpikir sebagai hasil dari keseluruhan proses nantinya (Weaver, 2007).

Sedangkan priming merupakan proses dimana media dalam menyajikan berita hanya berfokus pada sebagian isu sehingga mampu merubah standar evaluasi yang kerap dipakai publik dalam menilai realitas sosial yang ada dihadapannya (Severin \& Tankard, 2010). Dalam teori ini disebutkan bahwa penekanan pada sebuah fenomena memiliki hubungan sebab akibat dengan standar penilaian publik dan perhatian publik fenomena tertentu. Berhasil atau tidaknya proses priming yang dilakukan oleh media bergantung pada bagaimana media dapat dengan cermat mengetahui karakteristik audiensnya dalam menerima informasi. Baik itu dari sikap, cara pikir dan pandangan mayoritas hingga waktu yang tepat untuk menyajikan berita tersebut atau dikenal sebagai prime time.

Terlepas apapun itu fenomenanya, berita tidak akan bisa menceritakan fenomena itu sendiri. Jurnalis haurs mampu memilih elemen-elemen dari suatu situasi yang paling tepat dalammenyampaikan inti dari suatu fenomena. Bagaimana kebijakan redaksional suatu media mengkonstruksikan fakta-fakta yang ada terkait sebuah fenomena dalam membangun realitas disebut dengan framing. Frame atau bingkai merupakan konsep yang akan merangkum karakteristik dasar sebuah topik. Membingkai berarti memilih beberapa aspek dari realitas yang ada dan membuatnya lebih menojol dalam teks komunikasi (Entmant, 1993). Framing dapat berupa frasa, gambar, analogi, atau metafora yang digunakan media dalam mengomunikasikan esesnsi sebuah fenomena. Framing dinilai mampu menyederhanakan proses penyajian berita dan mengurangi kompleksitas masalah sehingga publik bisa lebih mudah mengerti mengenai fenomena yang berusaha disampaikan oleh media.

Framing dapat diartikan sebagai pemberian makna terhadap fenomena sosial melalui penyorotan dan pengemasan informasi oleh media. Framing memengaruhi bagaimana publik memahami sebuah fenomena yang pengaruhnya bergantung pada banyak faktor tingkat individu. Setelah publik memahami pesan yang berusaha disampaikan oleh media, maka publik tidak lagi hanya sebagai konten tetapi juga terlibat satu sama lain secara interpersonal dengan memanfaatkan pengetahuan serta pengalaman mereka (Gamson, 1996). Kemampuan yang dimiliki oleh media dalam menyebarkan informasi dalam kehidupan masyarakat kemudian menciptakan apa yang dikenal dengan masyarakat informasi. Masyarakat informasi dalam ranah Hubungan Internasional seringkali dugunakan sebagai konteks dalam menggambarkan bagaimana dunia seakan-akan sebuah desa yang sangat luas yang memiliki intensitas hubungan yang tinggi antara masyarakat disuatu negara dengan negara lainnya yang dapat dicapai melalui jaringan informasi yang pesat. Informasi 
tersebut kemudian didapatkan oleh seluruh masyarakat dunia sehingga akan mendorong terjadinya pembentukan opini publik secara mengglobal terkait sebuah fenomena.

\section{North Korea-United States Singapore Summit}

Pada tanggal 12 September 2018 telah terjadi pertemuan bersejarah antara Presiden Amerika Serikat, Donald Trump dan Pemimpin Republik Rakyat Demokratik Korea, Kim Jong Un di Singapura untuk pertama kalinya. Pertemuan tersebut menggemparkan dunia dikarenakan hubungan antar kedua pemimpin negara tersebut tidak pernah menunjukkan adanya keharmonisan sejak lama. Hal ini dimulai sejak diangkatnya Donald Trump menjadi Presiden Amerika Serikat secara resmi 2017 lalu. Dimasa awal kepemimpinanya, Trump banyak membuat kebijakan yang menuai konfrontasi. Begitu juga dengan sikapnya yang sangat tidak bersahabat dengan beberapa negara, salah satunya adalah Korea Utara. Dilansir dari salah satu konten interaktif yang tulis oleh Joshua Berlinger untuk CNN International, pada tahun 2017 merupakan puncak tensi antar keduanya terjadi disaat Trump mendeskripsikan Kim sebagai 'manusia roket'. Pada awal tahun 2018, Kim Jong Un menyampaikan sebuah pidato awal tahunnya yang berisikan pesan kebaikan pada Korea Selatan yang akan menggelar Winter Olympics Games. Dalam pidato yang sama juga, Kim menyampaikan bahwa misil nuklir milik negaranya diperkirakan telah mampu mencapai dataran Amerika Serikat. Presiden Korea Selatan, Moon Jae In merespon pidato Kim dengan menyampaikan ketersediaannya untuk bertemu dan berbincang. memberikan respon berupa sindiran kepada Kim.

Tak lama setelah 3rd Inter-Korean Summit dan sesaat setelah petemuan antara Korea Utara dan Korea Selatan yang berjalan dengan baik kemudian membuat Amerika Serikat berkeinginan untuk ikut berdiskusi dengan Korea Utara untuk membahas program denuklirisasi. Keinginan tersebut direalisasikan oleh Amerika Serikat dengan mengirimkan Menteri Luar Negeri menjabat, Mike Pompeo untuk bertemu langsung dengan Kim Jong Un di Pyongyang. Pertemuan tersebut diagendakan untuk mendiskusikan pertemuan antara Kim dan Trump yang pada akhirnya disepakati pada tanggal 12 Juni 2018 di Singapura.

Namun, perencanaan pertemuan ditemukan dengan beberapa kendala sebelum benar-benar terjadi. Pertama, masih terdapat banyak pertanyaan dan dibutuhkan klarifikasi lanjut mengenai proses denuklirisasi. Kedua, pada bulan Mei 2018, agenda pertemuan yang telah disepakati antara Kim dan Trump sempat terancam batal karena kedua belah pihak secara bergantian mengancam untuk membatalkannya. Dari pihak Korea Utara adalah pada saat terdapat bukti bahwa ternyata Korea Selatan dan Amerika Serikat masih melakukan latihan militer bersama dan hal ini dianggap tidak sesuai dengan semangat deklarasi yang telah ditandatangani oleh Kim dan Moon beberapa waktu lalu. Sedangkan dari pihak Amerika Serikat, keraguan bahwa Korea Utara akan berkomitmen denuklirisasi menjadi faktor utama membatalkan pertemuan tersebut. Selain itu, melalui 
surat terbuka, Donald Trump seakan menyudutkan pihak Korea Utara yang dianggap telah mengekspresikan retorika terhadap Amerika Serikat yang menghilangkan peluang kedua negara untuk berdamai (Morris, 2018). Namun demikian, Trump menyatakan bahwa ia masih akan menantikan untuk bisa bertemu dengan Kim Jong Un. Trump menambahkan bahwa jika Kim Jong Un bersedia mengubah rektorika anti Amerika Serikat yang dibuatnya, maka pihak Amerika akan mempertimbangkan kembali pertemuan tersebut.

Pertemuan bersejarah antara Donald Trump dan Kim Jong Un berhasil dilaksanakan pada Selasa, 12 Juni 2018 di Hotel Cappela, Singapura. Terpilihnya Singapura menjadi negara tempat pertemuan tersebut berlangsung karena beberapa alasan diluar permintaan dari pihak Amerika Serikat, yaitu tidak jauh dari Korea Utara, hubungan diplomatik yang baik antara Singapura dengan keduanya, terdapat sistem keamanan yang baik dan Singapura beberapa kali telah terpilih sebagai tempat pertemuan bersejarah. Pagi itu awak media dari berbagai negara telah bersiap untuk meliput fenomena tersebut dan menyaksikan kedua pemimpin negara kontroversial berjabat tangan.

Selama pertemuan berlangsung, kedua kepala negara tersebut melakukan diskusi mendalam yang berfokus pada denuklirirsasi, Hak Asasi Manusia, perbaharuan hubungan antara Amerika Serikat dengan Korea Utara dan memastikan perdamaian jangka panjang di Semenanjung Korea. Kedua belah pihak menyatakan komitmen mereka. Donald Trump berkomitmen untuk memberikan jaminan keamanan bagi Korea Utara, sementara Kim Jong Un menegaskan kembali posisinya mengenai denuklirisasi penuh Semenanjung Korea.

Diakhir pertemuan, sebuah pernyataan yang telah disepakati dan ditandatangi bersama dirilis dengan poin-poin berikut yang seharusnya dijadikan action plan bagi para aktor: pertama, Amerika Serikat dan Korea Utara berkomitmen untuk memperbaharui dan memperbaiki hubungan antar kedua belah pihak sesuai dengan keinginan rakyat demi perdamaian dan kesejahteraan; kedua, Amerika Serikat dan Korea Utara akan senantiasa bekerjasama dalam berupaya membangun rezim-rezim perdamaian yang stabil dan abadi di Semenanjung Korea; ketiga, Menegaskan kembali Deklarasi Panmunjom yang diadakan pada tanggal 27 April 2018 dimana Korea Utara berkomitmen untuk terus berusaha menuju denuklirisasi penuh Semenanjung Korea; keempat, Amerika Serikat menyetujui untuk melakukan penangguhan latihan militer gabungan dan mengindikasikan bahwa Kim telah berjanji untuk membongkar sebuah lokasi pengujian rudal balistik antarbenua; dan kelima, Amerika Serikat dan Korea Utara berkomitmen untuk memulihkan POW/MIA tetap, termasuk pemulangan segera dari yang telah teridentifikasi (Reuters 2018).

Pertemuan tingkat tinggi antara Kim dan Trump yang telah berhasil dilakukan dapat dilihat sebagai langkah besar dalam proses menciptakan perdamaian dunia. Sesaat setelah pertemuan diselenggarakan, banyak pihak yang merasa haru dan sorai karena tidak pernah terbayangkan sebelumnya 
bahwa pertemuan ini dapat direalisasikan. Korea Selatan, PBB, hingga Indonesia ikut optimis bahwa pertemuan ini aka membawa dunia pada babak perdamaian baru. Indonesia sebagai negara yang masih satu kawasan dengan Korea akan mendapat keuntungan berupa stabilitas keamanan setelah sebelumnya telah terjadi ketegangan yang dikhawatirkan akan berpuncak pada terjadinya perang terbuka. Selain itu, pertemuan tingkat tinggi tersebut juga diperkirakan dapat meningkatkan kekuatan diplomatik Indonesia dalam mengambil peran menciptakan perdamaian Semenanjung Korea. Dengan begitu, Indonesia bisa mendapatkan kepercayaan dari Korea Utara sehingga tujuan untuk memperbaiki hubungan Korea Utara dengan ASEAN juga dapat terealisasikan.

\section{Upaya Pembentukan Opini Publik oleh CNN Indonesia terkait 2018 North Korea-United States Singapore Summit}

Sejak awal kehadirannya pada 2014, CNN Indonesia selalu menyediakan deretan informasi terkait fenomena yang tejadi baik dari dalam negeri maupun dunia internasional. Hal ini merupakan bentuk pelaksanaan CNN Indonesia yang memiliki fungsi sebagai public sphere, yaitu sarana pembawa dan penyebar pesan kepada publik dengan akses yang terbuka dan memudahkan bagi audiensnya. Tidak terkecuali pada saat tercetusnya wacana mengenai akan diadakan pertemuan antara Kim Jong Un dan Donald Trump hingga terjadinya pertemuan bersejarah antara dua kepala negara yang telah lama bersitegang di Singapura pada 2018 lalu, hampir seluruh outlet media berita global mengambil peran dalam meliput fenomena ini.

Sebanyak kurang lebih 2,500 jurnalis televisi, cetak, dan daring dari seluruh dunia datang ke Singapura sejak 11 Juni 2018 pagi hari untuk melakukan peliputan pertemuan bersejarah yang baru akan dilakukan pada keesokan harinya. Para jurnalis tersebut ditempatkan di International Media Center yang berlokasi dalam gedung pit Formula 1, Marina Promade Park yang hanya berjarak sekitar 1,4 kilometer dari tempat pertemuan tersebut digelar. Para jurnalis disuguhkan dengan pelayanan terbaik dari pemerintah Singapura guna memenuhi kebutuhan mereka selama melaukan peliputan (Lim, 2018). Meskipun demikian, para jurnalis tetap tidak bisa meliput secara langsung dalam gedung pertemuan tersebut selama pertemuan berlangsung akibat ketatnya pengamanan. Awak media dikabarkan hanya bisa melihat ragkaian pertemuan tersebut melalui media center yang telah disediakan oleh Kominfo Singapura.

Salah satu kemitraan CNN yag ikut berpartisipasi dalam pertemuan bersejarah ini adalah CNN Indonesia. Apabila dilihat dari arsip yang dipublikasikan dalam portal berita cnnindonesia.com, maka audiens dapat menemukan banyak infografis terkait dinamika hubungan antara Kim Jong Un dan Donald Trump sejak awal masa kepemimpinan Trump hingga ke titik dimana keduanya sepakat untuk melakukan dialog terkait pertemuan perdana mereka dalam mencapai tujuan denuklirisasi demi kebermalahatan umat. Apabila dilihat dari arsip artikel yang telah dipublikasikan dalam 
laman cnnindonesia.com, terdapat sebanyak 135 artikel terkait 2018 North Korea-United States Singapore Summit sejak awal direncanakannya pertemuan tingkat tinggi tersebut hingga babak baru setelah pertemuan berlangsung. Selain berupa artikel, CNN Indonesia berupaya untuk melalukan inovasi dengan menyajikan konten-konten interaktif yang dapat menarik perhatian audiens seperti dengan video dan ilustrasi-ilustrasi dalam infografis yang publikasikan.

\section{Agenda-setting dalam Pemberitaan CNN Indonesia terhadap 2018 North Korea-United States Singapore}

Pada outlet media berita, agenda-setting dilakukan dengan memberikan penekanan pada intensitas dalam memberitakan suatu fenomena, termasuk jumlah artikel yang dipublikasikan oleh outlet media berita terkait dalam jangka waktu tertentu. Dalam melakukan peliputan terkait pertemuan bersejarah Kim Jong Un dan Donald Trump di Singapura pada 2018 lalu, CNN Indonesia cukup intens menyajikan informasi terkait fenomena tersebut. Sejak tercetusnya rencana akan digelar pertemuan Kim Jong Un dan Donald Trump pada tanggal 10 Mei 2018 hingga pasca terjadinya fenomena tersebut pada 14 Juni 2018, ditemukan sebanyak 135 artikel dan konten telah dipublikasikan oleh CNN Indonesia dalam laman portal resmi cnnindonesia.com.

Dalam tabel 1 (lihat lampiran) dapat dilihat bahwa CNN Indonesia mulai mempublikasikan artikel terkait pertemuan antara Kim Jong Un dan Donald Trump pertama kali pada 10 Mei 2018 sebayak dua artikel secara berurutan, dengan artikel pertama bertajuk "Trump Tak Bakal Bertemu Kim Jong Un di DMZ" dan disusul dengan artikel bertajuk "Trump Akan Bertemu Kim Jong Un di Singapura." Pemilihan judul tersebut tentunya sangat menggemparkan publik kala itu, mengingat hubungan antar dua kepala negara tersebut selalu tak pernah harmonis. Dua artikel yang berisikan informasi mengenai lokasi pertemuan dan Singapura adalah pilihan terkuat dengan alasan relatif dekat dengan Korea Utara secara geografis. Lima hari setelah pemberitaan tersebut, tepatnya pada 16 Mei 2018, CNN Indonesia kembali mempublikasikan artikel terkait pertemuan Kim Jong Un dan Donald Trump yang mana terancam batalnya pertemuan tersebut. Pada 17 Mei 2018, ditemukan sebayak lima artikel yang menceritakan ancaman Korea Utara untuk membatalkan pertemuan tersebut apabila Amerika Serikat terus menekan Korea Utara untuk menghentikan program nuklirnya.

Sejak tanggal 22 Mei 2018 hingga 27 Mei 2018, CNN Indonesia telah secara runtut mempublikasikan artikel sebanyak 15 artikel terkait aksi Kim Jong Un dan Donald Trump yang saling ancam dan mencetuskan kata batal untuk pertemuan yang telah direncakan sebelumnya. Sebanyak 10 dari 15 artikel yang dipublikasikan dalam kurun waktu tersebut, CNN Indonesia banyak memilih judul dengan mengambil sudut pandang Amerika Serikat dan 'Trump' sebagai kata pertama dalam judul artikel yang dipublikasikan. Hal ini secara tidak langsung membuat audiens CNN Indonesia lebih 
banyak mengetahui informasi terkait penyusunan rencana dan harapan pertemuan ini dari sudut pandang Donald Trump dan Amerika Serikat.

Setelah melalui proses tarik ulur yang cukup menarik untuk diikuti oleh publik terkait rencana pertemuan Kim Jong Un dan Donald Trump di Singapura, CNN Indonesia kembali memberikan informasi terkait perubahan pikiran dari Trump soal pertemuannya dengan Kim. Secara mendetail publik disajikan informasi bagaimana proses perencanaan kembali dilakukan, tertera sejak tanggal 28 Mei 2018 hingga 31 Mei 2018 terdapat tujuh artikel terkait perencanaan kembali tersebut. Memasuki bulan Juni 2018, pertemuan Kim Jong Un dan Donald Trump resmi digelar kembali. Pertanggal 01 Juni 2018 hingga 11 Juni 2018, ditemukan 44 artikel yang menginformasikan persiapan yang dilakukan oleh kedua belah pihak menjelang pertemuan berlangsung. Segala informasi terkait lokasi, akomodasi, pihak-pihak yang ikut berkontribusi, respons masyarakat, antusias media, dan harapan kedua belah pihak akan pertemuan bersejarah tersebut.

Pada hari terjadinya pertemuan antara Kim Jong Un dan Donald Trump, CNN Indonesia menjadi salah satu outlet media berita yang mengirimkan korespondensinya untuk melakukan peliputan secara langsung dari Singapura. Sebayak 41 artikel beserta video dipublikasikan pada tanggal 12 Juni 2018 dalam laman berita cnnindonesia.com. CNN Indonesia menyajikan informasi secara real time dan mendetail terkait pertemuan tersebut kepada para audiensnya yang dimulai dari tibanya kedua kepala negara di lokasi pertemuan, berlangsungnya dialog, proses penandatanganan dokumen terkait kesepakat kedua belah pihak hingga konferensi pers yang dilakukan oleh Donald Trump untuk menjawab semua pertanyaan yang berkenaan dengan jalannya pertemuan, hasil, hingga harapan kedepannya dalam upaya denuklirisasi dan menciptakan perdamaian dunia.

Pasca berlangsungnya pertemuan bersejarah tersebut, CNN Indonesia masih menyajikan informasi terkait fenomena tersebut kepada audiensnya. Terhitung sejak 13 Mei 2018 hingga 14 Mei 2018 ditemukan sebanyak lima artikel yang membahas tentang tanggapan dari Duta Besar Republik Indonesia untuk Korea Selatan, tanggapan Iran, hadiah Donald Trump untuk Kim Jong Un serta dukungan dari warga Amerika Serikat terkait kebijan yang dikeluarkan oleh presiden mereka dalam pertemuan tersebut.

Agenda-setting dalam prosesnya terbagi menjadi tiga tahapan, yaitu agenda media, agenda publik, dan agenda kebijakan. Sebuah informasi yang didapatkan oleh media akan melalui tahap seleksi dan diolah kembali oleh media sebagaimana fungsi media sebagai gatekeeper yang dimilikinya. Fungsi gatekeeper dijalankan oleh para perangkat aktor yang berperan dalam melakukan peliputan, seperti jurnalis, dan tim redaksi. Perangkat aktor tersebut memiliki pernanan yang esensial dalam mempengaruhi apa yang akan disajikan oleh media terkait suatu fenomena.

Berdasarkan publikasi artikel-artikel dalam laman cnnindonesia. com, maka dapat dikatakan bahwa agenda media CNN Indonesia dalam 
memberitakan 2018 North Korea-United States Singapore Summit adalah menggambarkan citra yang baik akan Kim Jong Un dan Donald Trump yang berupaya menciptakan perdamaian dunia dengan perjajian denuklirisasinya. Dalam menyajikan informasi terkait fenomena berserjarah tersebut, agenda media dari CNN Indonesia sesuai dengan visi dan misinya sebagai jendela dunia bagi Indonesia berupaya untuk membangun kesadaran masyarakat Indonesia tentang esensialitas dari perjajian denuklirisasi dan pentingnya mengaja perdamaian dunia. Sehingga kedepannya diharapkan bahwa masyarakat Indonesia dapat lebih peka dan bahkan berkontribusi dalam menciptakan perdamaian dunia.

Proses selanjutnya dalam agenda-setting adalah menentukan agenda kebijakan. Hal ini merupakan salah satu bentuk CNN Indonesia dalam melaksanakan fungsi media sebagai watch dog guna terus menyelaraskan kinerja pemerintah dengan harapan masyarakat (Robinson, 2008). Menurut teori agenda-setting, proses untuk sampai kepada agenda kebijakan banyaknya berangkat dari agenda media, dan berlaku sebaliknya. Dalam riset ini, kehadiran agenda kebijakan berangkat dari agenda media yang sebelumya telah dimunculkan oleh CNN Indonesia. Maka, agenda kebijakan CNN Indonesia adalah berupaya untuk membuka mata sekaligus mengingatkan pemerintah Indonesia bahwa Indonesia memiliki kapabilitas dalam berkontribusi menciptakan perdamaian dunia apabila Indonesia mau berusaha untuk lebih menujukkan eksistensinya dalam dunia internasional sebagaimana yang telah ditetapkan dalam UndangUndang Dasar 1945 alinea 4.

\section{Priming dalam Pemberitaan CNN Indonesia terhadap 2018 North Korea- United States Singapore}

Priming terjadi saat media mampu mengkonstruksi pikiran publik dengan menggiring perspektif atas isu atau fenomena yang sedang diberitakan (Vangshardt, 2009). Priming bekerja dengan menonjolkan isu atau fenomena apa yang memiliki urgensi dalam sebuah media berita. Dilihat dari artikel yang dipublikasikan oleh CNN Indonesia dalam memberitakan fenomena pertemuan antara Kim Jong Un dan Donald Trump di Singapura pada 2018 lalu, maka terdapat dua isu yang menjadi konsen oleh CNN Indonesia, yaitu denuklirisasi dan perdamaian dunia. Sejak awal rencana pertemuan kedua kepala negara ini dicetuskan, denuklirisasi merupakan isu yang sangat sering diangkat oleh CNN Indonesia.

Isu lainnya yang ditonjolkan oleh CNN Indonesia dalam memberitakan pertemuan Kim Jong Un dan Donald Trump di Singapura 2018 lalu adalah isu perdamaian dunia. Sejak pertama kali CNN Indonesia mempublikasikan artikel yang berjudul "Trump Akan Bertemu Kim Jong Un di Singapura" pada 10 Mei 2018, didalamnya telah disebutkan bahwa Donald Trump dalam akun twitter milikinya telah mengeluarkan penyataan resmi terkait pertemuannya dengan Kim Jong Un dan optimismenya bahwa pertemuan tersebut dapat menciptakan perdamaian dunia. CNN Indonesia banyak mengambil sudut pandang dari Amerika Serikat yang sangat 
mengharapkan terciptanya babak baru perdamaian dunia seiringan dengan pertemuan tersebut, hal ini ditunjukkan dari publikasi artikel pada tanggal 25 Mei 2018 yang berjudul "Pertemuan Batal, Gedung Putih Diskon Harga Koin Kim-Trump" yang didalammya mengatakan bahwa Gedung Putih telah membuat koin bergambar Kim dan Trump sebagai simbol menuju perdamaian antar dua negara tersebut. Artikel tersebut kemudian dapat menggiring publik untuk berpikir bahwa Amerika Serikat merupakan negara yang sangat menjunjung perdamaian dunia. Secara sadar ataupun tidak, dengan penjolan isu terkait denuklirisasi ini dalam artikel-artikel yang dipublikasikan oleh CNN Indonesia telah membangun kuriositas publik terkait denuklirisasi sehingga publik ingin mencari tahu mengapa denuklirisasi itu merupakan hal yang krusial dalam terciptanya babak baru perdamaian dunia.

\section{Framing dalam Pemberitaan CNN Indonesia terhadap 2018 North Korea- United States Singapore}

Fenomena bertemunya Kim Jong Un dan Donald Trump di Singapura 2018 lalu guna membahas denuklirisasi dan melangkah bersama untuk menciptakan perdamaian dunia yang lebih kekal tidak akan sampai kepada masyarakat dunia tanpa adanya publikasi dari media. Fenomena tidak akan bisa menceritakan fenomena itu sendiri. Media sendiri dalam melakukan pemberitaan tentunya memiliki kebijakan redaksional guna mengkonstruksikan fakta-fakta yang ada dalam membangun realitas. Kebijakan redaksional tersebut seringkali disebut sebagai framing.

Framing berarti memilih beberapa aspek dari realitas yang ada dan membuatnya lebih monjonjol dalam suatu teks artikel pemberitaan (Entmant, 1993). Pembingkaian berita yang dilakukan oleh media dinilai mampu menyederhanakan proses penyajian berita serta meminimalisir kompleksitas masalah sehingga publik dapat mengerti tentang fenomena yang berusaha disampaikan oleh media dengan lebih mudah. Diantara artikel-artikel yang telah di publikasikan oleh CNN Indonesia terkait pemberitaan pertemuan Kim Jong Un dan Donald Trump di Singapura Tahun 2018 lalu, terdapat beberapa yang memfokuskan pada pembangunan kesadaran akan pentingnya denuklirisasi guna menciptakan perdamaian dunia, baik yang tercantum dalam artikel yang mencaup laporan secara real time, maupun dengan mempublikasikan konten video. Jenis framing seperti ini dapat berkontribusi dalam mengkonstruk pikiran publik bahwa pertemuan antara Kim dan Trump di Singapura bukan hanya sebatas pertemuan antara dua kepala negara, tetapi juga sebagai langkah untuk menciptakan babak baru perdamaian dunia.

CNN Indonesia pertama kali mempublikasikan artikel terkait rencana pertemuan Kim Jong Un sejak tanggal 10 Mei 2018 dengan tajuk "Trump Tak Bakal Bertemu Kim Jong Un di DMZ" yang didalamnya membicarakan tentang posibilitas Singapura sebagai lokasi pertemuan keduanya dengan alasan Singapura merupakan negara yang netral dan secara geografis tergolong dekat dengan Korea Utara. Selain membahas terkait lokasi akan dilangsungkannya pertemuan, CNN Indonesia menambahkan narasi yang 
menggambarkan antusiasme Donald Trump guna mencapai kesepakatan bersejarah dalam denuklirisasi “... Trump juga menyatakan optimismenya atas prospek kesepakatan denuklirisasi, meski menyampaikan bahwa segalanya masih bisa gagal." Banyak hal-hal baik bisa terjadi, dan banyak hal buruk juga bisa terjadi," kata Trump seperti dilansir CNN. Meski begitu dia tetap optimistis bakal mencapai kesepakatan bersejarah untuk melucuti senjata nuklir (denuklirisasi) Korea Utara.

Masih dihari yang sama, CNN Indonesia dalam laman portal beritanya memberikan informasi kepada publik terkait wacana pertemuan antara Kim dan Trump dengan judul "Trump Akan Bertemu Kim Jong Un di Singapura" yang didalamnya membahas tentang besarnya keinginan Donald Trump untuk merencanakan pertemuan tersebut sesaat setelah Mike Pompeo melakukan kunjungan ke Pyongyang untuk membebaskan tiga warga negara Amerika Serikat yang sebelumnya menjadi tahanan Korea Utara. Diakhir artikel kemudian ditekankan bahwa pihak dari Amerika Serikat optimis akan pertemuan atar kedua kepala negara yang telah lama bersitegang dapat memberikan perubahan baik dengan melampirkan pernyataan dari Donald Trump: "Kami memulai dengan pijakan baru - saya benar-benar berpikir kami memiliki kesempatan yang sangat baik untuk melakukan sesuatu yang sangat berarti. Banyak hal yang sangat bagus telah terjadi." CNN Indonesia kemudian menyatakan dalam penulisannya bahwa Dia menyatakan sejauh ini belum pernah ada hubungan seperti ini. Trump menilai banyak kemajuan yang telah dibuat dalam hal ini: "Saya benar-benar berpikir dia ingin melakukan sesuatu dan membawa negara itu ke dunia nyata."

Saat rencana pertemuan antara Kim Jong Un dan Donald Trump dilanda drama saling ancam untuk membatalkan, CNN Indonesia juga terus memberikan informasi terkait dinamikanya kepada publik dengan narasi framing yang masih berkutat pada penekanan kata denuklirisasi dalam setiap artikelnya. Pada hari $\mathrm{H}$ pertemuan tingkat tinggi tersebut berlangsung, CNN Indonesia mempublikasikan sebanyak 41 artikel dengan laporan langsung dari Singapura sehingga publik dapat mengetahui perkembangan dari pertemuan tersebut secara real time. Dari isu-isu yang menjadi pembahasan dalam pertemuan tersebut, seperti denuklirisasi, akhir perang Korea, normalisasi hubungan antar dua negara, Hak Asasi Mausia, dan keamanan. CNN Indonesia hanya memfokuskan kepada isu denuklirisasi guna tercapainya perdamaian dunia. Hal ini dapat dilihat dari jumlah judul artikel yang menggunakan kata 'denuklirisasi' didalamnya terdapat 11 artikel, sedangkan isu lain seperti sanksi ekonomi yang diberikan Amerika Serikat untuk Korea Utara, kesepakatan pemberhentian latihan militer bersama antara Amerika Serikat dan Korea Selatan, serta isu Hak Asasi Manusia hanya ada satu judul artikel didalamnya persetiap isu. Hal ini menunjukkan secara gamblang bahwa CNN Indonesia ingin menekankan isu denuklirisasi dan perdamaian dunia kepada audiensnya.

Pada bagian tinjauan pustaka dalam riset ini, disebutkan bahwa framing memiliki dua tahapan utama, yaitu frame-building dan frame-setting 
(Schuefele, 1999). Frame-building merupakan cara media membangun berita dari potongan kehidupan publik sehari-hari, yang didasarkan oleh seperangkat norma sosial dimana media dan audiensnya berada. Dalam pemberitaan fenomena terkait pertemuan Kim Jong Un dan Donald Trump di Singapura 2018 lalu, upaya CNN Indonesia dalam melakukan framebuilding terkait fenomena tersebut dapat dilihat dari pemilihan kata yang digunakan dalam membentuk sebuah judul suatu artikel yang cenderung ringan dan ringkas sehingga membuat masyarakat Indonesia ingin membaca artikel tersebut.

Selain itu, frame-building juga merupakan cara bagaimana suatu media memandang dan mengkonstruk sebuah realitas yang dipengaruhi oleh faktor-faktor internal dan kebiasaan media tersebut (Shoemaker \& Resse, 1996). Sebagai salah satu bagian dari pelaksanaan strategi CNN International Commercial's Content Sales and Partnerships Group dengan cara membeli membeli lisensi milik CNN Internasional untuk melaukan penyiaran atas nama CNN secara resmi, CNN Indonesia selalu berusaha untuk mempertahankan standar editorial tertinggi serta menjunjung tinggi etika jurnalistik sesuai dengan standar yang telah ditetapkan oleh CNN Indonesia.

Berdasarkan analisis dari kumpulan artikel yang dapat ditemukan dalam laman cnnindonesia.com, pemilihan judul artikel yang dipilih CNN Indonesia beserta informasi yang berusaha disampaikan kepada publik kebanyakan mengambil dari sudut pandang Donald Trump ataupun Amerika Serikat. Sebayak 58 artikel dari 135 artikel yang dipublikasikan oleh CNN Indonesia menggambarkan sudut pandang Donald Trump dan juga pihak Amerika Serikat terkait pertemuan tersebut, sedangkan untuk Kim Jong Un dan Korea Utara hanya terdapat sebanyak 22 artikel saja. Selain itu, valensi yang disajikan oleh CNN Indonesia juga merupakan bentuk valensi yang positif, baik secara implisit maupun eksplisit, guna menggiring publik untuk beropini bahwa pihak Amerika Serikat memiliki attractiveness yang tinggi sebagai negara demokrasi untuk mengupayakan denuklirisasi yang utuh, menyeluruh dan juga terverifikasi agar babak baru perdamaian dunia yang telah diimpikan dapat segera direalisasikan. Jenis frame-building seperti ini terbukti telah berhasil dijalankan di Amerika Serikat dengan output berupa dukungan warga Amerika Serikat kepada Donald Trump karena sebelumnya kebijakan-kebijakan Trump kerap menjadi cemoohan dan menuai banyak kritik dari warganya sendiri hingga masyarakat internasional.

Tahap kedua dari proses framing yang dilakukan oleh media adalah frame-setting. Proses pengaturan ini bertujuan untuk mengkonstruksi keyakinan dan perasaan penerima terkait suatu fenomana yang diberitakan. Efek paling mendasar dari frame-setting adalah mampu memengaruhi penilaian atau sikap yang dimiliki seseorang berkenaan dengan fenomena yang dieberitakan. Dalam riset ini, frame-setting yang dilakukan oleh CNN Indonesia adalah untuk meyakinkan publik bahwa denuklirisasi dan perdamaian dunia merupakan hal esensial yag 
seharusnya menjadi perhatian setiap negara, bahkan individu. Guna mengkonstruksi keyakinan publik akan pentingnya isu tersebut, CNN Indonesia beberapa kali mempublikasikan artikel terkait pendapat para pihak-pihak elit internasional seperti Perserikatan Bangsa-Bangsa, analisis dari pakar Hubungan Internasional, hingga Presiden Republik Indonesia terkait pentingnya untuk memiliki keasadaran dan berkontribusi dalam menciptakan perdamaian dunia yang terangkum dalam artikel bertajuk "Sekjen PBB Prihatin Pertemuan Trump dan Kim Jong-un Batal" pada tanggal 25 Mei 2018, "PBB Desak Korut Bebaskan Ratusan Tahanan Jelang KTT dengan AS" pada tanggal 06 Juni 2018, "'Kekalahan' Indonesia di Balik Pertemuan Trump dan Kim" pada tanggal 11 Juni 2018, "Sekjen PBB Harapkan Kesepakatan Denuklirisasi dari Trump-Kim", "Pesohor Korsel Respons Pertemuan Kim Jong Un dan Donald Trump," dan "Jokowi Berharap Trump-Kim Berkontribusi pada Perdamaian Dunia" yang dipublikasikan pada hari H pertemuan bersejarah tersebut berlangsung, tepatnya pada 12 Juni 2018.

Artikel-artikel tersebut dipublikasikan oleh CNN Indonesia dengan harapan publik dapat lebih meningkatkan perhatiannya pada isu perdamaian dunia. Selain Perserikatan Bangsa-Bangsa yang telah dikenal sebagai wadah yang menyelesaikan segala liku permasalahan untuk menciptakan perdamaian dunia, CNN Indonesia merupakan media yang telah mengenal audiesnnya dengan baik. Presiden Joko Widodo merupakan sosok yang dianggap mampu merepresentasikan aspirasi masyarakat dan mampu mengarahkan rakyatnya dalam memandang suatu isu internasional. Kebijakan-kebijakan presiden selama ini telah menentukan bagaimana masyarakat menyikapi fenomena yang terjadi dalam dunia internasional. Sehingga diharapkan dengan mempublikasikan pernyataan resmi yang dikeluarkan oleh Presiden Joko Widodo, audiens CNN Indonesia dapat turut berkontribusi untuk menciptakan perdamaian dunia. Selanjutnya, framing yang paling unik adalah pengetahuan CNN Indonesia bahwa saat ini masyarakat Indonesia telah banyak yang keranjingan bintang-bintang Korea Selatan sehingga dengan membawa pendapat pesohor Korsel terkait harapan terciptanya perdamaian dunia setelah Pertemuan Kim Jong Un dan Donald Trump bertemu setidaknya bisa membuat publik bersikap yang sama dengan idol mereka.

Setelah berlagsungnya pertemuan bersejarah tersebut, CNN Indonesia masih terus melakukan frame-setting untuk meyakinkan publik bahwa fenomena yang sebulan belakangan diberitakan secara intensif adalah hal yang memang layak untuk diberitakan dan juga meyajikan publik dengan menggiring opini publik bahwa Amerika Serikat adalah satu-satunya negara yang mampu berdialog dengan Kim Jong Un guna berupaya bernegosiasi agar Korea Utara bersedia untuk melucuti senjata nuklirnya secara utuh, menyeluruh dan terverifikasi. Hal ini secara tidak langsung telah membuat publik berpikir bahwa Amerika Serikat merupakan negara demokratis yang dapat memanfaatkan label super power nya untuk kepentingan banyak pihak, yaitu menciptakan perdamaian dunia. Berhasil terlaksananya pertemuan ini juga telah menjadi capaian diplomatik terbesar semasa 
jabatan Donald Trump dan membuatnya masuk ke dalam daftar pemimpin yang patut diapresiasi. Citra Donald Trump juga semakin membaik saat publik disajikan pemberitaan tentang video yang diberikan oleh Trump untuk teman barunya, Kim Jong Un sebagai bentuk penyataan bahwa Trump telah meletakkan masa lalu hubungan kedua negara tersebut dan ia sekarang akan lebih berfokus pada kerjasama mereka di masa depan untuk menciptakan perdamaian dunia yang kekal dan abadi. Semua informasi tersebut terangkum dalam artikel yang dipublikasikan oleh CNN Indonesia pada tanggal 14 Juni 2018, dengan tajuk "'Kado Aneh' Donald Trump buat Kim Jong Un di Singapura" dan "Lebih dari Separuh Warga AS Dukung Kebijakan Trump soal Korut."

Dalam proses melakukan framing, CNN Indonesia telah berupaya untuk memberikan makna terhadap fenomena internasional yang patut untuk diperbincangankan - 2018 North Korea-United States Singapore Summit melalui penyorotan dan pengemasan informasi secara intensif. Framing yang dilakukan oleh CNN Indonesia telah membantu publik untuk memahami sebuah fenomena hingga tingkat individu, sehingga kedepannya diharapkan publik dapat berkontribusi untuk menciptakan perdamaian dunia dengan bekal informasi yang telah disajikan oleh CNN Indonesia melalui publikasi artikelnya. Hal ini juga selaras dengan fungsi media sebagai agen perubahan yang hadir untuk merubah sesuatu yang kurang baik menjadi lebih baik lagi terutama dalam sistem demokrasi, saat pers atau media merupakan pilar demokrasi keempat yang berperan banyak dalam menjaga keutuhan dan kelancaran jalannya demokrasi dalam suatu negara.

Framing CNN Indonesia yang berusaha membentuk opini publik dengan menanamkan citra yang baik akan Donald Trump dan Amerika Serikat merupakan salah satu contohnya nyata bahwa hingga saat ini, media masih menjadi salah satu alat propaganda yang bayak ditumpangi kepentingan-kepentingan elit politik dari negara-negara besar. Dengan terebentuknya opini publik berupa citra yang baik akan Donald Trump, maka hal ini juga akan berdampak pada citra Amerika Serikat yang dianggap menjadi negara yang mampu mengatasi setiap permasalahan yang ada di dunia internasional. 


\section{Kesimpulan}

Melalui analisis akhir menggunakan teori agenda-setting, priming, dan framing terkait fenomena 2018 North Korea-United States Singapore, ditemukan bahwa CNN Indonesia selain sebagai kepanjangan dari CNN Internasional tetapi juga sebagai negara penjunjung demokrasi serta sebagai negara sahabat bagi keduanya dalam artian memiliki hubungan diplomatik yang cukup erat selama bertahun-tahun, membentuk opini publik masyarakat Indonesia dengan berusaha semaksimal mungkin untuk tetap selaras dengan fungsinya sebagai watch dog dan public sphere di Indonesia dengan mempromosikan isu perdamaian dunia yang selama ini telah menjadi agenda politik luar negeri Indonesia. Tetapi di sisi lain CNN Indonesia dalam menyajikan pemberitaan terkait fenomena 2018 North Korea-United States Singapore masih sangat mengikuti standar redaksional dari $\mathrm{CNN}$ Internasional, yang mana secara tidak langsung telah dijadikan alat propaganda untuk mempromosikan kepentingankepentingan Amerika Serikat.

Terkait agenda-setting, CNN Indonesia telah melakukan publikasi secara intensif sejak satu bulan sebelum pertemuan berlangsung tepatnya sejak bulan Mei 2018 dengan publikasi mencapai 135 artikel yang kemudian menggiring publik untuk berpikir bahwa fenomena tersebut merupakan suatu isu yang patut untuk dibicarakan dan disikusikan di ruang publik. Dari 135 artikel yang dipublikasikan oleh CNN Indonesia terkait fenomena 2018 North Korea-United States Singapore, terdapat dua isu yang paling ditekankan yaitu denuklirisasi da perdamaian dunia yang kemudian dapat diidentifikasikan sebagai bentuk priming dari CNN Indonesia guna membagun opini publik terkait pentingnya berkontribusi dalam menciptakan perdamaian dunia sebagaimana tercantum dalam agenda politik luar negeri Indonesia yang bebas aktif.

Untuk membuktikan premis diawal bahwa media global selama ini kerap dijadikan sebagai alat propaganda untuk mencapai kepentingan suatu negara, semua terdapat dalam analisis framing yang dilakukan oleh CNN Indonesia terkait fenomena 2018 North Korea-United States Singapore dengan ditemukan sebanyak 58 artikel dari 135 artikel yang dipublikasikan oleh CNN Indonesia menggambarkan sudut pandang Donald Trump dan juga pihak Amerika Serikat terkait pertemuan tersebut, sedangkan untuk sudut pandang yang berasal dari Kim Jong Un dan Korea Utara hanya terdapat sebanyak 22 artikel saja. Selain itu, valensi yang disajikan oleh CNN Indonesia juga merupakan bentuk valensi yang positif, seperti antusiasme, optimism, dan juga harapan dari Donald Trump juga Amerika Serikat. Hal ini dapat menggiring publik untuk beropini bahwa pihak Amerika Serikat memiliki daya tarik yang tinggi sebagai negara demokrasi dalam mengupayakan denuklirisasi yang utuh, menyeluruh dan juga terverifikasi agar babak baru perdamaian dunia yang telah diimpikan sejak lama oleh seluruh masyarakat dunia dapat segera direalisasikan. 


\section{Daftar Pustaka}

Baylis, J., Smith, S., \& Owens, P. (2014) An Introduction to International Relations. Oxford: Oxford University Press.

Chadwick, A. (2013) The Hybrid Media System. Oxford: Oxford University Press.

Coban, F. (2016). The Role of the Media in International Relations: From the CNN. Journal of International Relations and Foreign Policy, 4 (2), pp. 45-61.

Deil, S. A. (2014) Chairul Tanjung Kibarkan CNN Indonesia [Online], Liputan 6. Tersedia dalam: <https://www.liputan6.com/bisnis/read/2017025/ chairul-tanjung-kibarkan-cnn-indonesia> [Diakses 1 September 2019].

Entmant, R. M. (1993). Framing: Toward Clarification of a Fractured Paradigm. Journal of Communication, 43 (4), pp. 51-58.

Flournoy, D. (1992) CNN World Report: Ted Turner's International News Coup. London: John Libbey \& Company Ltd.

Gamson, W. A. (1996). Media Discourse as a Framing Resoursce. In: A. N. Clinger. The Psychology of Political Communication. Ann Arbor: University of Michigan Press.

Hill, C. (2003) The Changing Politics of Foreign Policy. New York: Palgrave Macmillan.

McCombs, M. E., \& Shaw, D. L. (1972). The Agenda-setting Function of Mass Media. The Public Opinion Quarterly, 36(2), pp. 176-18.

Price, V. (2011). Public Opinion Research in the New Century. Public Opinion Quarterly, 75(5), pp. 846-853.

Robinson, P. (2008). The Role of Media and Public Opinion. In: S. Smith, A. Hadfield, \& T. Dunne. Foreign Policy: Theories, Actors, Cases. Oxford: Oxford University Press.

Schuefele, D. A. (1999). Framing as a Theory of Media Effects. Journal of Communication, 49(1), pp. 103-122.

Severin, W. J., \& Tankard, J. W. (2010) Communication Theories: Origins, Methods and Uses in the Mass Media. New York: Addison Wesley Longman, Inc.

Weaver, D. H. (2007). Thoughts on Agenda Setting, Framing, and Priming. Journal of Communication, 57(1), pp. 142-147. 
Lampiran

Tabel 1

Artikel-atikel yang dipublikasikan oleh CNN Indonesia terkait fenomena Pertemuan Kim Jong Un dan Donald Trump di Singapura Tahun 2018, periode 10 Mei 2018 - 14 Juni 2018.

\begin{tabular}{|c|c|c|}
\hline No. & Tanggal Publikasi & Judul Artikel \\
\hline 1. & $10 / 05 / 2018$ & Trump Akan Bertemu Kim Jong Un di Singapura \\
\hline 2. & $10 / 05 / 2018$ & Trump Tak Bakal Bertemu Kim Jong Un di DMZ \\
\hline 3. & $16 / 05 / 2018$ & Korut Tak Terima Disudutkan AS soal Pelucutan Nuklir \\
\hline 4. & $17 / 05 / 2018$ & Korut Tunda Dialog dengan Korsel, Ancam Batal Temui Trump \\
\hline 5. & $17 / 05 / 2018$ & Korut: Dialog dan Latihan Perang Tak Bisa Beriringan di Korea \\
\hline 6. & $17 / 05 / 2018$ & VIDEO: Korut Ancam Batalkan Pertemuan dengan Trump \\
\hline 7. & $17 / 05 / 2018$ & AS Dilaporkan Minta Korut Kirimkan Hulu Ledak Nuklir dan ICBM \\
\hline 8. & $17 / 05 / 2018$ & Trump Irit Bicara setelah Diancam Korut \\
\hline 9. & $17 / 05 / 2018$ & Pertemuan Trump dan Kim Jong Un Terancam, Korsel Turun Tangan \\
\hline 10. & $18 / 05 / 2018$ & Penasihat Keamanan Trump Yakin KTT AS-Korut Tetap Berlangsung \\
\hline 11. & $18 / 05 / 2018$ & Trump Ancam Kim Jong-un, Denuklirisasi atau Seperti Gaddafi \\
\hline 12. & $22 / 05 / 2018$ & Wapres AS: Trump Bisa Batal Bertemu Kim Jong Un \\
\hline 13. & $23 / 05 / 2018$ & Trump Ragu Pertemuan dengan Kim Jong Un Terjadi Juni Nanti \\
\hline 14. & $24 / 05 / 2018$ & Trump Batalkan Pertemuan dengan Kim Jong Un \\
\hline 15. & $25 / 05 / 2018$ & Trump Batalkan Pertemuan dengan Kim Jong Un \\
\hline 16. & $25 / 05 / 2018$ & Wamenlu Korut Sebut Pernyataan Wapres AS 'bodoh' \\
\hline 17. & $25 / 05 / 2018$ & Trump Sebut Keputusan Pertemuan Kim Ditentukan Pekan Depan \\
\hline 18. & $25 / 05 / 2018$ & Pertemuan Trump-Kim Batal, Warga AS Disebut Bakal Kecewa \\
\hline 19. & $25 / 05 / 2018$ & VIDEO: Pertemuan Donald Trump dan Kim Jong Un Batal \\
\hline 20. & $25 / 05 / 2018$ & Isi Lengkap Surat Trump untuk Kim Jong Un Soal Batal Bertemu \\
\hline 21. & $25 / 05 / 2018$ & Analisis: Ketulusan Korut, Provokasi AS dan Aksi Koboi Trump \\
\hline 22. & $25 / 05 / 2018$ & Sekjen PBB Prihatin Pertemuan Trump dan Kim Jong-un Batal \\
\hline 23. & $25 / 05 / 2018$ & Pertemuan Batal, Gedung Putih Diskon Harga Koin Kim-Trump \\
\hline 24. & $25 / 05 / 2018$ & Kim-Trump Batal Jumpa, Korsel Sebut Korut Tetap Denuklirisasi \\
\hline 25. & $25 / 05 / 2018$ & Trump Batal Temui Kim, Korut Tetap Buka Diri untuk Dialog \\
\hline 26. & $25 / 05 / 2018$ & Batal Temui Kim Jong Un, Trump Dinilai Merugi \\
\hline 27. & $25 / 05 / 2018$ & Batal Bertemu, Kim-Trump Masuk Jalur Cepat Menuju Konflik \\
\hline 28. & $26 / 05 / 2018$ & VIDEO: Trump Berubah Pikiran Soal Pertemuan dengan Korut \\
\hline 29. & $26 / 05 / 2018$ & Trump-Kim Batal Jumpa, China Desak AS-Korut Tetap Berdialog \\
\hline 30. & $26 / 05 / 2018$ & Sempat Batal, Trump Wacanakan Kembali Bertemu Kim Jong Un \\
\hline 31. & $26 / 05 / 2018$ & Batal Bertemu Trump, Kim Jong-un Kembali Jumpa Moon Jae-in \\
\hline 32. & $26 / 05 / 2018$ & Netizen Ejek Surat Trump buat Kim Jong-un, Beri Nilai 'F' \\
\hline 32. & $27 / 05 / 2018$ & Cerita di Balik Tarik Ulur Trump Bertemu Kim Jong Un \\
\hline 33. & $27 / 05 / 2018$ & Korsel Sebut Kim Jong-un Bertekad Temui Trump \\
\hline 35. & $28 / 05 / 2018$ & VIDEO: Pertemuan Trump dan Kim Jong Un Kembali Disiapkan \\
\hline
\end{tabular}




\begin{tabular}{|c|c|c|}
\hline 36. & $28 / 05 / 2018$ & Presiden Korsel Kemungkinan Ikut Pertemuan Kim dan Trump \\
\hline 37. & $28 / 05 / 2018$ & AS Kirim Tim ke Korut untuk Persiapan Petemuan Trump-Kim \\
\hline 38. & 29/05/2018 & Trump Akan Temui Shinzo Abe Sebelum Kim Jong Un \\
\hline 39. & $29 / 05 / 2018$ & Donald Trump Sambut Kedatangan Utusan Kim Jong-un ke New York \\
\hline 40. & 29/05/2018 & Persiapan Bertemu Trump, Utusan Kim Jong-un Tiba di Singapura \\
\hline 41. & $31 / 05 / 2018$ & Menlu AS dan Utusan Kim Jong-un Bahas KTT Sambil Santap Steik \\
\hline 42. & $31 / 05 / 2018$ & Tangan Kanan Kim Jong-un, Menlu Pompeo Bahas Persiapan KTT \\
\hline 43. & $01 / 06 / 2018$ & Menlu Rusia Sambangi Korut Jelang Pertemuan Trump dan Kim \\
\hline 44. & $02 / 06 / 2018$ & VIDEO: Trump Pastikan Bertemu Kim Jong Un 12 Juni \\
\hline 45. & $02 / 06 / 2018$ & Trump Bakal Terima Surat dari Kim Jong Un \\
\hline 46. & $02 / 06 / 2018$ & Terima Surat dari Kim Jong-un, Trump Bersiap Dapat Kejutan \\
\hline 47. & $02 / 06 / 2018$ & Trump Pastikan Temui Kim Jong Un Sesuai Jadwal \\
\hline 48. & 02/06/2018 & Canda Warganet soal Ukuran Surat Kim Jong-un untuk Trump \\
\hline 49. & 03/06/2018 & Bakal Pertemuan Trump-Kim Sisakan Pertanyaan Biaya Akomodasi \\
\hline 50. & 06/06/2018 & Trump dan Kim Jong-un Bertemu di Pulau Sentosa \\
\hline 51. & 06/06/2018 & VIDEO: Melongok Lokasi Pertemuan Trump - Kim di Pulau Sentosa \\
\hline 52. & $06 / 06 / 2018$ & KTT Trump-Kim, Singapura Perketat Penerbangan 11-13 Juni \\
\hline 53. & $06 / 06 / 2018$ & Korut Krisis, AS Tak Tanggung Hotel Kim Jong Un di Singapura \\
\hline 54. & $06 / 06 / 2018$ & Dennis Rodman ke Singapura saat Kim Jong-un Bertemu Trump \\
\hline 55. & 06/06/2018 & PBB Desak Korut Bebaskan Ratusan Tahanan Jelang KTT dengan AS \\
\hline 56. & 06/06/2018 & Dari Ancaman ke Pelukan, Perubahan 'Senjata' Kim Jong-un \\
\hline 57. & 07/06/2018 & Pengacara: Kim Jong-un Mengemis untuk Bertemu Trump \\
\hline 58. & 07/06/2018 & AS Siapkan Pertemuan Hari Kedua Trump dan Kim Jong-un \\
\hline 59. & 07/06/2018 & Menlu Singapura ke Korut Jelang Trump Temui Kim Jong-un \\
\hline 60. & 08/06/2018 & Kim Jong-un dan Trump Akan Tiba di Singapura pada Minggu \\
\hline 61. & 08/06/2018 & Trump Berencana Undang Kim Jong-un ke Gedung Putih Seusai KTT \\
\hline 62. & 08/06/2018 & Bertemu PM Jepang, Trump Ungkap Isi Surat Kim Jong-Un \\
\hline 63. & 09/06/2018 & Kim Jong-un Jadi-jadian Sempat Ditahan di Bandara Singapura \\
\hline 64. & $10 / 06 / 2018$ & Warga Penuhi Hotel Sambut Kedatangan Kim Jong Un di Singapura \\
\hline 65. & $10 / 06 / 2018$ & Trump Yakin Perjalanan ke Singapura Tak Akan Percuma \\
\hline 66. & $10 / 06 / 2018$ & Donald Trump Tiba di Singapura untuk Temui Kim Jong Un \\
\hline 67. & $10 / 06 / 2018$ & ‘Burger Trump-Kim’ Ramaikan Pertemuan AS dan Korut \\
\hline 68. & $11 / 06 / 2018$ & FOTO: Pulau Sentosa, Lokasi Jabat Tangan AS-Korea Utara \\
\hline 69. & $11 / 06 / 2018$ & Trump dan Kim Jong-un: Dari Saling Hina Hingga Mau Bertemu \\
\hline 70. & $11 / 06 / 2018$ & Trump-Kim Akan Bicarakan Mekanisme Perdamaian Yang Kekal \\
\hline 71. & $11 / 06 / 2018$ & 'Kekalahan' Indonesia di Balik Pertemuan Trump dan Kim \\
\hline 72. & $11 / 06 / 2018$ & AS Siap Jamin Keamanan Korut jika Mau Denuklirisasi) \\
\hline 73. & $11 / 06 / 2018$ & VIDEO: Euforia Warga Singapura Sambut Kim-Trump \\
\hline 74. & $11 / 06 / 2018$ & Kim Jong-un Dilaporkan Undang Trump ke Korut \\
\hline 75. & $11 / 06 / 2018$ & Pejabat Korut-AS Siapkan KTT Trump-Kim Jong Un \\
\hline 76. & $11 / 06 / 2018$ & FOTO: Pengamanan Diperketat Jelang Pertemuan Kim dan Trump \\
\hline
\end{tabular}




\begin{tabular}{|c|c|c|}
\hline 77. & $11 / 06 / 2018$ & Jelang KTT Kim-Trump, Menlu AS Tegaskan Niat Denuklirisasi \\
\hline 78. & $11 / 06 / 2018$ & Donald Trump Temui PM Singapura di Istana \\
\hline 79. & $11 / 06 / 2018$ & Kim dan Trump Belum Tentu Sepakati Denuklirisasi \\
\hline 80. & $11 / 06 / 2018$ & Penyiar Propaganda Korut Kabarkan Pertemuan Kim dan Trump \\
\hline 81. & $11 / 06 / 2018$ & Pertemuan Trump-Kim Jong-un Jadi Berita Utama Koran Singapura \\
\hline 82. & $11 / 06 / 2018$ & Pertemuan Trump-Kim Diliput 2.500 Jurnalis Seluruh Dunia \\
\hline 83. & $11 / 06 / 2018$ & KTT Trump-Kim, Singapura Deportasi Dua Staf Media Korsel \\
\hline 84. & $11 / 06 / 2018$ & Saat Delegasi Korut Nikmati Hasil Kapitalisme Singapura \\
\hline 85. & $11 / 06 / 2018$ & Jelang KTT Trump-Kim, Polisi Sterilkan Lokasi Pertemuan \\
\hline 86. & $11 / 06 / 2018$ & KTT AS-Korut, Tamu Hotel Dilarang Memotret Kim Jong-un \\
\hline 87. & $11 / 06 / 2018$ & Donald Trump Rayakan Ulang Tahun di Istana Singapura \\
\hline 88. & $12 / 06 / 2018$ & Kim Lebih Dulu Tiba di Lokasi Pertemuan dari Trump \\
\hline 89. & $12 / 06 / 2018$ & Kim Jong-un, Misteri Sang Pemimpin Negara Terisolasi \\
\hline 90. & $12 / 06 / 2018$ & Malam sebelum KTT, 'Kim Jong-un' Kunjungi Bar di Singapura \\
\hline 91. & $12 / 06 / 2018$ & Presiden Korsel: Trump-Kim Hancurkan Warisan Perang Dingin \\
\hline 92. & $12 / 06 / 2018$ & Kim Jong-un: Tak Mudah Bertemu Donald Trump \\
\hline 93. & $12 / 06 / 2018$ & Jempol Trump buat Kim Jong-un di Pertemuan Bersejarah \\
\hline 94. & $12 / 06 / 2018$ & Temui Kim Jong-un, Trump Sebut Perang Korea Segera Berakhir \\
\hline 95. & $12 / 06 / 2018$ & Trump-Kim Bahas HAM, Sepakat Pulangkan Jenazah Korban Perang \\
\hline 96. & $12 / 06 / 2018$ & Trump: Sanksi Terhadap Korut Belum akan Dicabut \\
\hline 97. & $12 / 06 / 2018$ & Usai Temui Kim, Trump Sepakat Hentikan Latihan Militer \\
\hline 98. & $12 / 06 / 2018$ & Trump: Kim Jong-un Segera Melucuti Senjata Nuklir \\
\hline 99. & $12 / 06 / 2018$ & VIDEO: Bersama Trump, Konferensi Pers Perdana Kim Jong-un \\
\hline 100. & $12 / 06 / 2018$ & Kim Jong-un: Bertemu Trump adalah Awal Baik Menuju Perdamaian \\
\hline 101. & $12 / 06 / 2018$ & Pertemuan Kim dan Trump, Ketika AS Perlakukan Korut Setara \\
\hline 102. & $12 / 06 / 2018$ & Adik Kim Jong-un Tukar Pulpen Sebelum Teken di Detik Terakhir \\
\hline 103. & $12 / 06 / 2018$ & Dokumen: Trump dan Kim Sepakat Denuklirisasi Utuh \\
\hline 104. & $12 / 06 / 2018$ & Kim Jong-un Bungkam Ditanya Denuklirisasi \\
\hline 105. & $12 / 06 / 2018$ & Sekjen PBB Harapkan Kesepakatan Denuklirisasi dari Trump-Kim \\
\hline 106. & $12 / 06 / 2018$ & FOTO: Pertemuan Bersejarah Donald Trump dan Kim Jong-un \\
\hline 107. & $12 / 06 / 2018$ & Isak Haru Dennis Rodman Soal Pertemuan Trump dan Kim \\
\hline 108. & $12 / 06 / 2018$ & Trump: Bakal Ada yang Diteken Usai Makan Siang dengan Kim \\
\hline 109. & $12 / 06 / 2018$ & Video: Jabat Tangan Bersejarah Trump - Kim \\
\hline 110. & $12 / 06 / 2018$ & Kim Jong-un: Dunia akan Lihat Perubahan Besar \\
\hline 111. & $12 / 06 / 2018$ & Trump dan Kim Jong-un Teken Dokumen Bersejarah \\
\hline 112. & $12 / 06 / 2018$ & Isu Penting dalam Pertemuan Kim Jong-un dan Donald Trump \\
\hline 113. & $12 / 06 / 2018$ & Trump Sebut Proses Denuklirisasi Berjalan Cepat \\
\hline 114. & $12 / 06 / 2018$ & Jokowi Berharap Trump-Kim Berkontribusi pada Perdamaian Dunia \\
\hline 115. & $12 / 06 / 2018$ & Sisi Gelap Pulau Sentosa, Lokasi Pertemuan Trump-Kim Jong-un \\
\hline 116. & $12 / 06 / 2018$ & Trump Sebut Kim Jong-un Janji Hancurkan Situs Uji Coba Rudal \\
\hline 117. & $12 / 06 / 2018$ & Pesohor Korsel Respons Pertemuan Kim Jong Un dan Donald Trump \\
\hline
\end{tabular}




\begin{tabular}{|r|r|r|}
\hline 118. & $12 / 06 / 2018$ & Mengintip Isi Perjanjian Trump dan Kim Jong-un \\
\hline 119. & $12 / 06 / 2018$ & INFOGRAFIS: Rambut Ikonik Donald Trump VS Kim Jong Un \\
\hline 120. & $12 / 06 / 2018$ & Menyingkap Kisah di Balik Rambut Nyentrik Kim Jong Un \\
\hline 121. & $12 / 06 / 2018$ & VIDEO: Pertama Kali, Delegasi Trump Duduk Bersama Kim Jong-un \\
\hline 122. & $12 / 06 / 2018$ & VIDEO: Trump Sebut Korut Hancurkan Situs Uji Rudal Utamanya \\
\hline 123. & $12 / 06 / 2018$ & VIDEO: Trump Sebut Perlucutan Rudal Butuh Waktu Lama \\
\hline 124. & $12 / 06 / 2018$ & VIDEO: Hentikan Latihan Militer dengan Korsel, Trump Dikritik \\
\hline 125. & $12 / 06 / 2018$ & VIDEO: Trump Percaya Kim Jong-un Akan Lucuti Nuklir \\
\hline 126. & $12 / 06 / 2018$ & 1 Jam ‘Bersama' Donald Trump di Capella Hotel \\
\hline 127. & $12 / 06 / 2018$ & Selesai Bertemu Kim Jong-un, Trump Tinggalkan Singapura \\
\hline 128. & $12 / 06 / 2018$ & Trump Sebut Kemungkinan Temui Kim Jong-un di Pyongyang \\
\hline 129. & $12 / 06 / 2018$ & Trump: Kim Jong-un Segera Melucuti Senjata Nuklir \\
\hline 130. & $12 / 06 / 2018$ & Dubes RI: Kesepakatan Bersama Trump-Kim Memberi Harapan \\
\hline 131. & $12 / 06 / 2018$ & Iran Peringatkan Kim Jong-un: Trump Bisa Batalkan Perjanjian \\
\hline 132. & $12 / 06 / 2018$ & File Intelijen Ungkap Masa Kecil Kim Jong-un \\
\hline 133. & $12 / 06 / 2018$ & 'Diplomasi Basket’ Dennis Rodman ke Korut Berlanjut \\
\hline 134. & $12 / 06 / 2018$ & 'Kado Aneh' Donald Trump buat Kim Jong Un di Singapura \\
\hline 135. & $12 / 06 / 2018$ & Lebih dari Separuh Warga AS Dukung Kebijakan Trump soal Korut \\
\hline
\end{tabular}

Sumber: CNN Indonesia, 2018. 